\title{
MICROCOLONY DETECTION IN THIN LAYER CULTURE AS AN ALTERNATIVE METHOD FOR RAPID DETECTION OF MYCOBACTERIUM TUBERCULOSIS IN CLINICAL SAMPLES
}

\author{
Pedro Eduardo Almeida da Silva ${ }^{1 *}$; Fernanda Wiesel ${ }^{1}$; Maria Marta Santos Boffo ${ }^{1}$; Andréa von Groll ${ }^{1}$; \\ Ivo Gomes de Mattos ${ }^{1}$; Glória Mejia²; Jaime Robledo
}

${ }^{1}$ Fundação Universidade Federal do Rio Grande, Departamento de Patologia, Rio Grande, RS, Brasil; ${ }^{2}$ Corporación para Investigaciones, CIB, Escuela de Ciencias de la Salud, UPB, Medellín, Colombia

Submitted: August 25, 2006; Returned to authors for corrections: November 10, 2006; Approved: July 29, 2007.

\section{SHORT COMMUNICATION}

\begin{abstract}
Tuberculosis remains one of the major causes of mortality worldwide. The early detection of new cases is an important goal in the program of tuberculosis control. Several methodologies for rapid and accurate laboratorial diagnosis have been developed, however, some of these techniques are expensive or cumbersome, making their implementation in low-income regions unfeasible. In this study, the thin layer culture method was compared with conventional culture method and it was observed that it provides earlier results and a presumptive species identification, being adequate alternative method for rapid laboratory diagnosis.
\end{abstract}

Key words: tuberculosis, rapid diagnosis, Mycobacterium tuberculosis

Recently the World Health Organization (WHO, 2006) reaffirmed that the two main targets for tuberculosis (TB) global control are the diagnosis of $70 \%$ of all smear positive TB cases and the successful treatment of $85 \%$ of them (1).

The diagnosis is an important tool for TB control because it allows establishing the correct treatment and the required further control practices to break down the transmission chain of the bacilli. Conventional laboratorial methods for diagnosis of TB are sputum microscopy and culture in Lowenstein-Jensen or Ogawa medium $(2,3)$. However, these methodologies present low sensitivity or take a long time to achieve results. Even though there are several new methodologies with higher specificity and/ or sensitivity able to provide earlier results than the conventional methodologies, the implementation of these alternative methods in the routine of the majority of the laboratories around the world is very difficult because of their high cost and complexity (4-6).

The development of new, inexpensive, and more sensitive methodologies for TB diagnosis able to provide earlier results than the conventional methods is a priority for TB control.
The detection of microcolonies has been described as an alternative method for the definitive diagnosis of TB $(7,8,9)$, providing more rapid results and presumptive species identification. This study evaluated the sensitivity and time for detection of positive cultures with the microcolony method, Middlebrook 7H11 Thin Layer agar plate (TL7H11) (8) against the results in the conventional culture in Ogawa medium.

In the study, 154 specimens (130 pulmonary and 24 extrapulmonary) were evaluated. The specimens were obtained from patients with clinical signs of TB, admitted in the University Hospital of Rio Grande, in the southernmost region of Brazil, between August 2003 and March 2004. Clinical samples were analyzed for acid fast organisms using Kinyoun microscopy. Using swabs, each samples was transferred to a set of four tubes: one with 2\% Ogawa-Kudoh medium (10), one with OgawaKudoh plus $1 \mu \mathrm{g} / \mathrm{ml}$ of acid thiophene-2-carboxylic acid hydrazide (TCH), one with Ogawa-Kudoh plus $500 \mu \mathrm{g} / \mathrm{ml}$ of pnitro-benzoic acid (PNB) and one with Ogawa-Kudoh plus $\mu \mathrm{g} /$ $\mathrm{ml}$ of piruvate. This is the official strategy proposed by the

*Corresponding Author. Mailing address: Fundação Universidade Federal do Rio Grande - FURG - Departamento de Patologia - Brasil. Tel.: (53) 32338895. E-mail: pedre@furg.br ou pedre_99@yahoo.com.br 
Brazilian Ministry of Health for initial identification of Mycobacterium tuberculosis complex (11). Using a different swab, the same samples were transferred to $60 \mathrm{~mm} \times 15 \mathrm{~mm}$ plates containing $5 \mathrm{ml}$ of TL7H11 medium (Middlebrook 7H11 medium with 10\% OADC: oleic acid, albumin, dextrose and catalase, obtained from Becton, Dickinson and Company, Sparks, MD USA) plus piperacillin, trimethoprim and amphotericin (Sigma $\left.{ }^{\circledR}\right)$ at $0.05 \mu \mathrm{g} / \mathrm{ml}, 0.02 \mu \mathrm{g} / \mathrm{ml}$ and $0.02 \mu \mathrm{g} / \mathrm{ml}$ respectively.

For both culture methods, prior to the inoculations, clinical specimens were decontaminated by the introduction of a sterile swab first into the specimens and then into a tube with $4 \%$ $\mathrm{NaOH}$ solution for two minutes. The cultures were incubated at $37^{\circ} \mathrm{C}$, in a hermetically sealed candle jar for $\mathrm{CO}_{2}$ enrichment. The observations were carried out daily and performed by naked eye for the Ogawa medium and by optical microscopy (10x objective) for the TL7H11 plastic plates. The strains initially identified as M. tuberculosis by their microcolony morphology (9) were submitted to microscopic examination for acid-fast organisms and confirmed with classical biochemical methods for TB identification (niacin, catalase and nitratase assays).

Among the 154 samples studied, 37 and 39 were positive cultures in TL7H11 and Ogawa medium, respectively. The average time for obtaining positive results in all samples (pulmonary and extra-pulmonary) was nine days for microcolony visualization in TL7H11 and twenty-one days for the observation of the colonies in the Ogawa medium (Fig. 1). Eighty nine pulmonary samples resulted negative when evaluated by microscopy. From these, three samples were positive for culture in both methods. Among the 24 extra-pulmonary samples, four positive results were observed: two for both methods, one only for the TL7H11 method, and one only for the Ogawa medium.

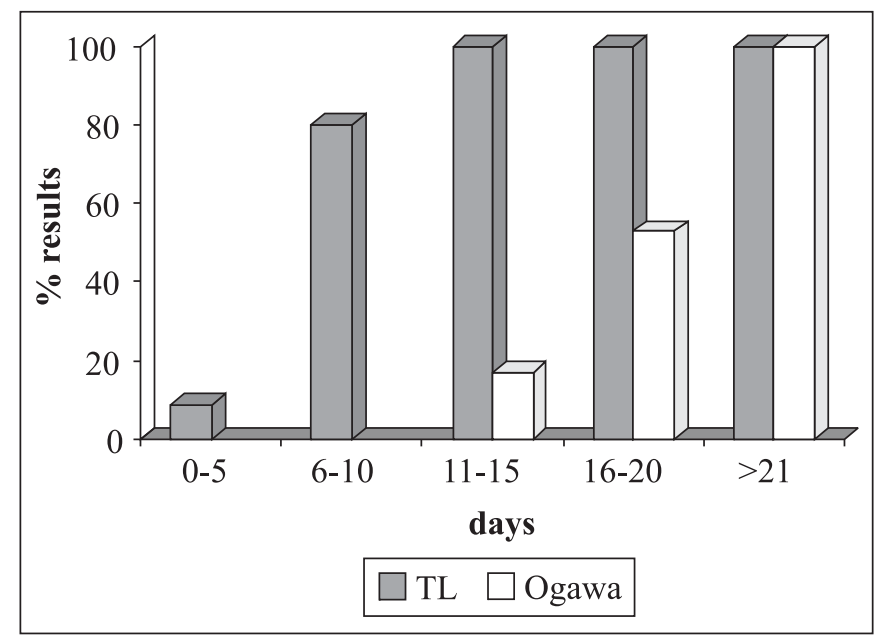

Figure 1. Cumulative percentage of $M$. tuberculosis positive results pulmonary and extra-pulmonary samples using Middlebrook 7H11 Thin Layer (TL) method and Ogawa media.
All extra-pulmonary samples were negative by the optical microscopy analysis. The average time for colony detection in the extra-pulmonary samples was 13 days for the TL7H11 method and 23 days for the Ogawa medium.

Our results show that cultures by both conventional and/or alternative methods increase the sensitivity of laboratorial diagnosis with both pulmonary and extra-pulmonary samples. The percentage of positive cultures was similar for both methods: $2.5 \%$ and $2.3 \%$ for the TL7H11 method and Ogawa media, respectively. The Mycobacterium tuberculosis complex was the only species identified. Putative species identification by microcolony morphology (Fig. 2) was confirmed by biochemical assays.

The significant reduction in the time for identification of a positive result achieved by the TL7H11 method allows an earlier implementation of treatment, which is crucial for breaking the TB transmission chain.

Although present worldwide, the incidence of TB is higher in poor regions, where tools for controlling this disease are necessary. The culture in thin layer medium presents advantages, such as simple execution, easy interpretation, and faster results than conventional cultures. Results of this work confirm that this method a reliable alternative method for the diagnosis of TB and for preliminary species identification. However, further controlled evaluations such as inter- and intra-laboratory validation and impact on patients, are necessary for its eventual implementation of this method in the routine diagnosis.

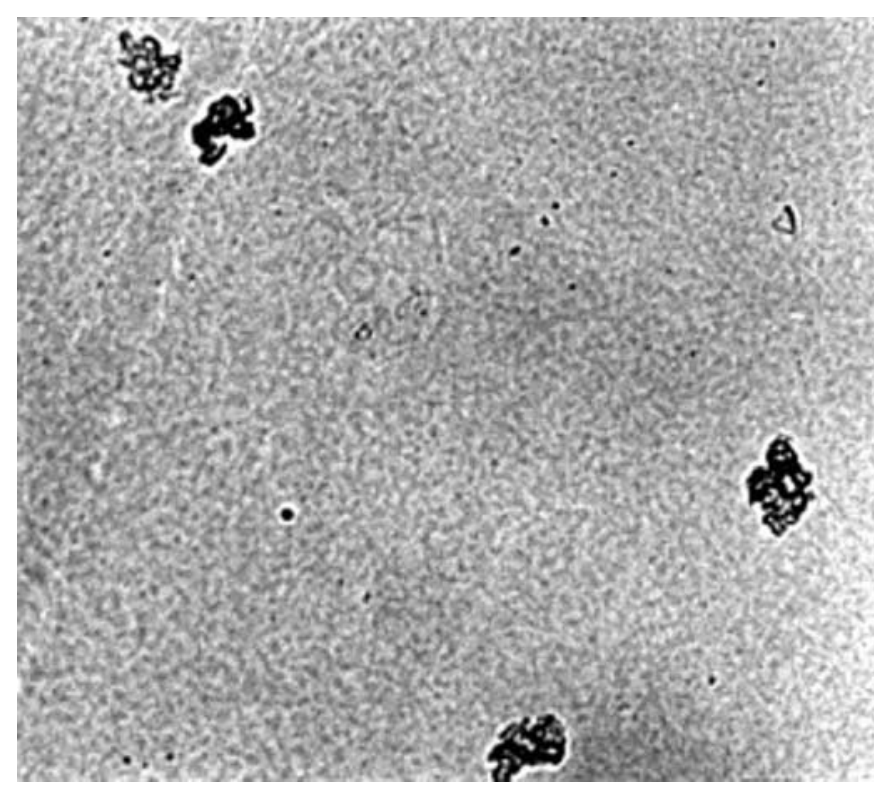

Figure 2. Photomicrography of the microcolonies of $M$. tuberculosis on Middlebrook 7H11 Thin Layer medium. The image was taken through the bottom of the plastic Petri dish at magnification of $400 \mathrm{x}$. The microcolonies are circa 7 days old. 


\section{ACKNOWLEDGEMENTS}

This study was partially supported by the European Commission under the INCO-DEV Programme (Project No. ICA4-CT-2001-10087) and the UNICEF / UNDP/World Bank / WHO / Special Programme for Research and Training in Tropical Diseases (TDR)

\section{RESUMO}

\section{Detecção de microcolônias em cultivo de camada delgada como uma alternativo para a rápida detecção de Mycobacterium tuberculosis em amostras clínicas}

A tuberculose permanece como uma das principais causas de mortalidade em todo o mundo. A detecção precoce dos casos novos é um importante ponto nos programas de controle da tuberculose. Diversas metodologias para um rápido e acurado diagnóstico laboratorial tem sido desenvolvidas, entretanto, algumas destas técnicas são de alto custo ou de difícil execução, tornando inexeqüível sua implementação em locais com poucos recursos. Neste trabalho o método de cultivo em camada delgada foi comparado ao método de cultivo convencional verificandose apresenta resultados positivos em menor tempo com uma identificação presuntiva da espécie de micobactéria, sendo assim um método alternativo adequado para o diagnóstico laboratorial rápido.

Palavras chave: tuberculose, diagnóstico rápido, Mycobacterium tuberculosis

\section{REFERENCES}

1. WHO (2006). Global tuberculosis control - surveillance, planning, financing

2. Tanoue, S.; Mitarai, S.; Shishido, H. (2002). Comparative study on the use of solid media: Löwenstein-Jensen and Ogawa in the determination of antituberculosis drug susceptibility. Tuberc., 82(2/ 3), 63-67.

3. Perkins, M.D.; Roscigno, G.; Zumla, A. (2006). Progress towards improved tuberculosis diagnostics for developing countries. Lancet. (367) 942-43

4. Drobniewski, F.A.; Caws, M.; Gibson, A.; Young, D. (2003). Modern laboratory diagnosis of tuberculosis. Lancet Infect. Dis., (3)141-147.

5. Palomino, J.C. (2005). Nonconventional and new methods in the diagnosis of tuberculosis: feasibly and applicability in the field. Eur. Respir. J., 26(2) 1-12

6. Anjos Filho, L.; Oelemann, W.M.R.; Barreto, C.E.N.; Kritski, A.L.; Fonseca, L.S. (2002). Sensitivity of Amplicor MTB on Direct Detection of Mycobacterium tuberculosis in Smear-Negative Specimens from Outpatients in Rio De Janeiro Braz. J. Microbiol., $33(2)$.

7. Idigoras, P.; Perez-Trallero, E.; Alcorta, M.; Gutierrez, C.; MunozBaroja, I. (1995). Rapid detection of tuberculous and non-tuberculous mycobacteria by microscopic observation of growth on Middlebrook 7H11 agar. Eur. J. Clin. Microbiol. Infect. Dis., 14(1): 6-10.

8. Mejia, G.I.; Castrillon, L.; Trujillo, H.; Robledo, J.A. (1999). Microcolony detection in 7H11 thin layer culture is an alternative for rapid diagnosis of tuberculosis Biomedica, 24(1): 52-9.

9. Mejia, G.I..; Guzman, A.; Agudelo, C.A.; Trujillo, H.; Robledo, J. (2004). Five year experience with thin layer medium for rapid diagnosis of Mycobacterium tuberculosis infection. Int. J. Tuberc. Lung. Dis., 3(2): 138-42.

10. Susemihl, M.A.; Ferrazoli, L.; Ueki, S.Y.M.; Gimenez, R.D.; Palaci, M. (1993). Avaliação do método de Ogawa-Kudoh para o cultivo de micobactérias. Rev. Bras. Patol. Clín., v.29, n.2, p.51-54.

11. Brasil. Ministério da Saúde. (1993). Manual de bacteriologia da tuberculose e de outras micobacterioses: isolamento de micobactérias. 